\title{
Hubungan Pengetahuan dengan Sikap Ibu Nifas Tentang Pijat Oksitosin di Puskesmas Bergas
}

\author{
Susi Purwanti ${ }^{1}$, Moneca Diah Listiyaningsih ${ }^{2}$ \\ ${ }^{1,2}$ Kebidanan Program Sarjana, Universitas Ngudi Waluyo \\ Email: monecalis88@gmail.com
}

\begin{abstract}
ABSTRAK
Mengacu pada program WHO pada tahun 2025 sasaran pemberian ASI eksklusif minimal 50\%. Maka secara nasional cakupan ASI Eksklusif di Puskesmas Bergas sebesar $48 \%$ belum terpenuhi. Alasan utama Ibu tidak memberikan ASI secara eksklusif adalah pada hari-hari pertama pasca melahirkan ASI keluar tidak lancar, sehingga ibu lebih memilih memberikan bayinya susu formula. Pijat Oksitosin adalah upaya mengatasi ketidaklancaran ASI. Tujuan penelitian adalah mengetahui hubungan pengetahuan dengan sikap ibu nifas tentang pijat oksitosin di Puskesmas Bergas. Desain penelitian ini korelasi dengan jumlah populasi Ibu nifas pada bulan Oktober-November 2020 sebanyak 35 responden, sampel penelitian berjumlah 35 responden dengan tekhnik pengambilan sampel total sampling. Instrumen yang digunakan adalah kuesioner dengan analisis data menggunakan uji Chi Square. Hasil analisis univariat variabel pengetahuan menunjukkan pengetahuan responden sebagian besar baik, yaitu sebesar 13 responden (37,2\%). Dan variabel sikap menunjukkan sebanyak 51,4\% responden memiliki sikap negatif. Analisis Bivariat didapatkan nilai sigifikansi sebesar $0,016(\alpha<0,05)$, sehingga $\mathrm{H}_{0}$ ditolak dan $\mathrm{H}_{\mathrm{a}}$ diterima. Maka dapat disimpulkan bahwa ada hubungan pengetahuan dengan sikap ibu nifas tentang pijat oksitosin di Puskesmas Bergas Tahun 2020. Terdapat hubungan antara pengetahuan dengan sikap ibu nifas tentang pijat oksitosin di Puskesmas Bergas Tahun 2020.
\end{abstract}

Kata Kunci :Pengetahuan, Sikap, Pijat Oksitosin

\begin{abstract}
The Correlation Betweenof Knowledge With The Attitudes Of Postpartum About Oxytosin Massage In Bergas Health Center Year 2020

Referring to WHO program in 2025 targets exclusive breastfeeding of at least $50 \%$. So nationally, the coverage of exclusive breastfeeding at the Bergas Health Center is $48 \%$. The main reason for mothers not to exclusively breastfeed them is that in the first days after delivery the milk does not come out smoothly, so mothers prefer to give their babies formula milk. Oxytocin massage is an attempt to overcome the unsustainability of breast milk. The research objective was to determine the correlation between of knowledge and postpartum mothers' attitudes about oxytocin massage at the Bergas Health Center. Design of this research iscorrelation with the total population of postpartum mothers in October-November 2020 as many as 35 respondents, the study sample was 35 respondents with a total sampling technique. The instrumen used was a questionnaire with data analysis using the Chi Square test. The results of the univariate analysis of the knowledge variable showed that the respondents' knowledge was mostly good, namely 13
\end{abstract}


respondents (37.2\%). And the attitude variable shows that $51.4 \%$ of respondents have negative attitudes. Bivariate analysis obtained sigifikansi value of 0,016 ( $\alpha$ $<0.05)$, so that $H_{0 i s}$ rejected and $H_{a}$ accepted. So it can be concluded that there is a relationship between knowledge and postpartum mothers 'attitudes about oxytocin massage at the Bergas Health Center in 2020. There is a relationship between knowledge and postpartum mothers' attitudes about oxytocin massage at the Bergas Health Center in 2020.

Keywords: Knowledge, Attitude, Oxytocin Massage

\section{PENDAHULUAN}

Masa nifas (puerpurium) adalah masa setelah plasenta lahir dan berakhir ketika alat-alat kandungan kembali seperti keadaan sebelum hamil, berlangsung kira-kira 6 mingguatau 42 hari (Suprijati, 2014). Modal awal pembentukan manusia yang memiliki khualitas baik dan unggul adalah dimulai sejak bayi dalam kandungan disertai dengan pemberian Air Susu Ibu (ASI) sejak usia dini. ASI membantu petumbuhan dan perkembangan bayi secara optimal serta melindungi terhadap penyakit. Air Susu Ibu (ASI) akan memberikan manfaat lebih optimal jika pemberiannya dilakukan secara eksklusif tanpa pemberian makanan tambahan lain selama 6 bulan pertama kehidupan.

Di Puskesmas Bergas Kabupaten Semarang cakupan ASI eksklusif tahun 2019 sebesar 48\% (220 bayi dari 459) jumlah bayi umur 0-6 bulan. Hal ini mengalami peningkatan dari tahun 2018. Capaian ASI eksklusif tertinggi di Kelurahan Karangjati sebesar 86,8\% (59 dari 68 bayi), sedangkan terendah di Desa Pagersari 11,5\% yaitu 3 dari 26 bayi. Alasan utama ibu tidak memberikan ASI secara eksklusif di Desa Pagersari adalah karena pada mingguminggu pertama pasca melahirkan ASI belum keluar secara maksimal sehingga ibu enggan memberikan ASI dan lebih memilih memberikan susu formula dengan alasan kasihan kepada bayinya karena belum mendapat ASI secara sempurna.

Berdasarkan data diatas alasan tidak pemberian ASI secara eksklusif presentasi terbesar adalah pada karena ASI tidak keluar pada pasca persalinan. Ibu pasca melahirkan lebih memilih tidak memberikan ASI nya karena pada kondisi tersebut ASI belum mampu keluar secara maksimal. Ketidaklancaran produksi Air Susu Ibu (ASI) pada hari-hari pertama pasca melahirkan dapat disebabkan karena kurangnya rangsangan hormon oksitosin dan prolaktin yang berperan dalam kelancaran proses produksi ASI, oleh karenanya ASI tidak segera keluar setelah melahirkan. Hormon oksitosin bekerja untuk memacu refleks pengeluaran ASI Let Down Reflex (LDR) sehingga produksi ASI meningkat dan kebutuhan akan ASI pada bayi mampu terpenuhi dengan baik (Nurul Isnani dan Rama Diyanti, 2015).

Menurut jurnal penelitian Nurul Isnani dan Rama Diyanti (2015) upaya intervensi yang dilakukan untuk pengeluaran hormon oksitosin ini adalah dengan melakukan pijat oksitosin. Pijat oksitosin merupakan salah satu terapi pijat ASI yangpemijatannya dilakukan pada tulang belakang tepatnya pada os. Costa (tulang rusuk) ke 5-6 sampai ke scapula 
(tulang belikat) yang akan mempercepat proses kerja saraf parasimpatis yaitu saraf yang terletak pada ujung pangkal medulla oblongata dan pada daerah tulang sacrum dari medulla spinalis. Oleh karena itulah saraf parasimpatis disebut juga saraf craniosacral yang merangsang hipofise posterior untuk mengeluarkan hormon oksitosin, hormon oksitosin menstimulasi kontraksi sel-sel otot polos yang melingkari duktus laktiferus kelenjar payudara yang dapat menyebabkan berkontraksinya mioepite lpada payudara sehingga dapat meningkatkan pengeluaran ASI dari kelenjar payudara itu sendiri.

Menurut Tutik Rahayuningsih (2020) faktor-faktor yang mempengaruhi pelaksanaan pijat oksitosin pada ibu nifas adalah pengetahuan, sosial budaya dan dukungan keluarga. Pengetahuan menjadi salah satu faktor utama yang dapat mempengaruhi pelaksanaan pijat oksitosin pada ibu nifas karena semakin baik pengetahuan ibu tentang sesuatu hal maka akan meningkatkan perilaku positif ibu dalam melakukan hal tersebut.

Pengetahuan adalah hasil dari memahami suatu objek atau sesuatu, dan ini terjadi setelah seseorang merasakan suatu objek. Sensasi dapat terjadi melalui indera manusia, termasuk penglihatan, pendengaran, penciuman, pengecapan dan peraba. Namun secara umum pengetahuan manusia diperoleh melalui penglihatan dan pendengaran (Notoatmodjo, 2011).

Sedangkan sikap merupakan reaksi respon yang masih tertutup dari seseorang terhadap suatu stimulus atau objek tertentu yang belum dapat diketahui kebenarannya menurut Notoatmodjo (2011). Sikap belum tentu hasil suatu tindakan atau aktivitas, akan tetapi lebih pada merupakan predisposisi tindakan suatu perilaku. Sikap merupakan reaksi tertutup seseorang, bukan merupakan reaksi terbuka atau tingkah laku yang terbuka. Sikap merupakan kesiapan untuk bereaksi terhadap objek di lingkungan tertentu sebagai suatu penghayatan terhadap objek (Notoatmodjo, 2011).

Berdasarkan studi pendahuluan yang dilakukan pada tanggal 23 Oktober 2020 pada 10 orang ibu nifas yang melahirkan di Puskesmas Bergas, dari hasil wawancara didapatkan hasil 4 dari ibu nifas 2 orang (20\%) sudah mengetahui pengertian pijat oksitosin, manfaat dan langkahlangkah melakukan pijat oksitosin, namun 2 (20\%) diantaranya lagi mengetahui tentang pijat oksitosin tetapi belum tahu langkah-langkah melakukan pijat oksitosin yang baik dan benar, dan 6 dari $10(60 \%) \mathrm{ibu}$ nifas lainnya belum mengetahui tentang pijat oksitosin, manfaat dan langkah melakukannya, hal ini di karenakan pengetahuan ibu yang kurang tentang pijat oksitosin. Sedangkan untuk sikap ibu nifas, dari 10 ibu nifas, 2 (20\%) ibu menyikapi positif dan sangat setuju jika ibu nifas sebaiknya melakukan pijat oksitosin karena dapat mengatasi masalah pengeluaran ASI yang tidak lancar. Sedangkan $8(80 \%)$ orang ibu nifas menyikapi negatif tentang pijat oksitosin yaitu tidak setuju jika ibu nifas sebaiknya rutin melakukan pijat oksitosin untuk membantu memperlancar produksi ASI.

Sehubungan dengan itu maka peneliti tertarik untuk melakukan penelitian lebih lanjut tentang "Hubungan Pengetahuan Dengan Sikap Ibu Nifas Tentang Pijat 
Oksitosin di Puskesmas Bergas Tahun 2020".

\section{METODE PENELITIAN}

Desain penelitian yang digunakan dalam penelitian ini adalah studi korelasi dengan metode pendekatan yang digunakan adalah pendekatan cross sectional. Populasi dalam penelitian ini adalah data ibu nifas yang melahirkan di Puskesmas Bergas selama bulan OktoberNovember 2020 sejumlah 35 ibu

\begin{tabular}{lcc}
\hline \multicolumn{1}{c}{ Pengetahuan } & Frekuensi & Persentase (\%) \\
\hline Kurang & 11 & 31.4 \\
Cukup & 11 & 31.4 \\
Baik & 13 & 37.2 \\
\hline \multicolumn{1}{c}{ Jumlah } & 35 & 100,0 \\
\hline
\end{tabular}

Berdasarkan tabel diatas hasil penelitian menunjukkan bahwa pengetahuan ibu nifas tentang pijat oksitosin di Puskesmas Bergas Tahun 2020 sebagian besar baik sebanyak 13 responden $(37,2 \%)$. Pengetahuan ibu nifas yang baik tentang pijat oksitosin didukung oleh sebagian besar umur responden yang memiliki pengetahuan baik adalah masuk dalam kategori reproduksi sehat yaitu sebesar 12 responden (92,3\%). Hal tersebut menunjukan bahwa seiring bertambahnya usia, seseorang akan memiliki lebih banyak pengalaman dan pengetahuan. Kecerdasan seseorang masih dapat berperan dengan baik di masa dewasa. Semakin dewasa seseorang, semakin berkembang cara berpikirnya, semakin besar kemungkinan memperoleh informasi, begitu pula sebaliknya semakin tua pula pemikirannya. Hal ini sejalan pula dengan penelitian terdahulu yang dilakukan oleh Astuti (2011), terdapat hubungan antara usia dengan tingkat pengetahuan seseorang dengan nilai $(\rho=0,001)$, dan usia yang nifas. Dengan sampel penelitian berjumlah 35 ibu nifas dengan teknik pengembilan sampel total sampling. Penelitian ini menggunakan instrumen kuesioner dan analisis data menggunakan uji chi-square.

\section{HASIL DAN PEMBAHASAN}

Tabel 1 Gambaran Pengetahuan Ibu Nifas Tentang Pijat Oksitosin di Puskesmas Bergas Tahun 2020

diwawancarai adalah 20-35 (usia reproduksi). Semakin produktif usia seseorang maka tingkat ilmunya akan semakin matang.

\begin{tabular}{ccc}
\multicolumn{2}{c}{ Berdasarkan } & distribusi \\
jawaban & responden & kuesioner
\end{tabular} variabel pengetahuan menunjukkan bahwa dari 35 responden penelitian di Puskesmas Bergas yang memiliki pengetahuan baik responden yang paling banyak menjawab benar adalah pernyataan nomor 15 yaitu Pijat oksitosin tidak bisa dilakukan sendiri melainkan dengan bantuan suami atau keluarga yang lain sebanyak 35 responden (100\%).

Pengetahuan ibu nifas dalam penelitian ini sebagian besar baik juga faktor lain disebabkan ibu nifas mendapatkan informasi tentang pijat oksitosin saat ada penyuluhan oleh tenaga kesehatan di Puskesmas Bergas sesaat setelah melahirkan sebelum pulang ke rumah. Hal ini sesuai dengan teori yang diungkapkan menurut (Triwibowo, 2015 :36) bahwa pengetahuan adalah hasil dari "mengetahui" dan terjadi setelah seseorang merasakan suatu objek tertentu melalui indra manusia seperti 
pendengaran dan penglihatan. Pengetahuan ini berasal dari segala informasi yang didapatkan oleh ibu nifas dari berbagai macam sumber.

Hasil penelitian ini didukung oleh penelitian terdahulu yang dilakukan oleh Novita A (2016) yang menyatakan bahwa pengetahuan tentang pijat oksitosin dari $21 \mathrm{ibu}$ nifas pada bulan Juni 2016 di BPM Isna Junaedi Dusun Bandungan Gedangan Kecamatan Tuntang Kabupaten Semarang menunjukkan bahwa sebagian besar pengetahuan responden cukup sebanyak 9 responden $(42,9 \%)$, baik sebanyak 8 responden $(38,1 \%)$ dan kurang sebanyak 4 respondsen (19,0\%). Pengetahuan cukup yang didapatkan dari hasil penelitian ini disebabkan responden telah mendapatkan informasi dari bidan mengenai pijat oksitoksin yaitu pijatan untuk merangsang ASI. Bidan memberikan konseling kepada responden setelah melahirkan.

cukup dalam penelitian in
didominasi dan didukung oleh pendidikan responden yaitu dengan pendidikan menengah dan pendidikan tinggi sebanyak 23 responden $(95,8 \%)$. Pendidikan merupakan salah satu faktor yang cukup untuk mendukung kemampuan berfikir seseorang. Status pendidikan dapat mempengaruhi seseorang dalam memperoleh informasi dimana dengan pendidikan yang tinggi seseorang akan lebih mudah menyerap informasi yang didapat terutama tentang pijat oksitosin. Tingkat pendidikan seseorang berpengaruh terhadap pengetahuan yang dimiliki dimana pendidikan yang lebih tinggi memberi respon yang lebih terbuka terhadap informasi yang berguna bagi responden (Wawan, 2011).

Tabel 2 Gambaran Sikap Ibu Nifas

Tentang Pijat Oksitosin di

Puskesmas Bergas Tahun 2020

Sikap Frekuensi Persentase

\begin{tabular}{ccc} 
& & $(\%)$ \\
\hline Negatif & 18 & 51.4 \\
Positif & 17 & 48.6 \\
\hline Jumlah & 35 & 100,0 \\
\hline
\end{tabular}

Berdasarkan tabel 2 hasil penelitian ini menunjukkan bahwa mayoritas responden memiliki sikap yang negatif tentang pijat oksitosin sebanyak 18 responden $(51,4 \%)$. Sikap negatif ibu nifas tentang pijat oksitosin disebabkan pengaruh orang di sekitar yang tidak mendukung adanya langkah pijat oksitosin untuk membantu ibu nifas memperlancar pengeluaran ASI. Orang disekitar kita merupakan salah satu diantara komponen sosial yang ikut mempengaruhi sikap kita, seseorang yang kita anggap penting. Seseorang yang kita anggap penting, seseorang yang kita harapkan persetujuan bagi setiap gerak tingkah dan pendapat kita, seseorang yang tidak ingin kita kecewakan, atau seseorang yang berarti khusus bagi kita akan banyak mempengaruhi pembentukan sikap kita terhadap sesuatu. Diantara orang yang biasanya dianggap penting bagi individu adalah orangtua, orang yang status sosialnya lebih tinggi, teman sebaya, teman dekat, teman kerja, dan suami. Kecenderungan ini antara lain dimotivasi oleh keinginan untuk menghindari konflik dengan orang yang dianggap penting tersebut.

Sikap negatif terlihat pada $65,9 \%$ ragu dan tidak setuju dengan 
pernyataan nomor 7 dimana Ibu nifas sebaiknya melakukan pijat oksitoksin untuk membantu rahim kembali seperti semula sebelum hamil dan $22,8 \%$ menjawab setuju pernyataan nomor 8 yaitu saya akan diam saja jika ASI saya keluar tidak lancar. Sedangkan sikap positif pada penelitian ini dapat dilihat sebanyak $62,2 \%$ tidak setuju pada pernyataan nomor 2 yaitu menurut saya, pijat oksitosin tidak membantu tubuh saya menjadi lebih nyaman dan rileks.

Menurut hasil penelitian terdahulu yang dilakukan oleh Novita A. (2016) sikap negatif terlihat pada $42,9 \%$ tidak setuju dengan pernyataan no 13 dimana akan melakukan pijat oksitoksin untuk mempertahankan produksi ASI, 38,1\% tidak setuju dengan pernyataan nomor 7 dimana menurut ibu pemijaatan di lakukan oleh suami atau keluarga saya dan tidak setuju dengan pernyataan no 6 dimana ibu akan melakukan pijat oksitoksin untuk membantu rahim kembali seperti semula setelah melahirkan. Sikap negatif ditunjukkan karena ibu nifas belum memiliki pengetahuan yang cukup baik tentang pijat oksitosin.

Tabel 3 Hubungan Pengetahuan

Dengan Sikap Ibu Nifas Tentang

Pijat Oksitosin di Puskesmas Bergas

Tahun 2020

\begin{tabular}{|c|c|c|c|c|c|c|}
\hline & \multicolumn{4}{|c|}{ Sikap } & \multirow{3}{*}{ Total } & \multirow{3}{*}{$\begin{array}{c}p- \\
\text { value }\end{array}$} \\
\hline & \multicolumn{2}{|c|}{ Positif } & \multicolumn{2}{|c|}{ Negatif } & & \\
\hline & $\mathbf{N}$ & $\%$ & $\mathbf{N}$ & $\%$ & & \\
\hline Baik & 10 & 76.9 & 3 & 23.1 & 13 & \\
\hline Cukup & 5 & 45.5 & 6 & 54.5 & 11 & \\
\hline Kurang & 2 & 18.2 & 9 & 81.8 & 11 & 0.016 \\
\hline Jumlah & 17 & 48.6 & 18 & 51.4 & 35 & \\
\hline
\end{tabular}

Berdasarkan hasil penelitian yang dilakukan di Puskesmas Bergas Kabupaten Semarang, dari $35 \mathrm{ibu}$ nifas ditemukan bahwa sebagian besar ibu nifas memiliki pengetahuan yang baik dan sikap positif berjumlah 10 orang ibu nifas (76,9\%), sedangkan ibu nifas yang memiliki pengetahuan baik dan sikap negatif berjumlah 3 orang ibu nifas $(23,1 \%)$. Hal ini disebabkan dengan pengetahuan yang baik seseorang akan membentuk sikap yang positif tentang pijat oksitosin.

Hal ini sejalan dengan teori yang diungkapkan Green dalam Notoatmodjo (2010) bahwa pengetahuan merupakan faktor predisposisi yang menentukan terbentuknya sikap dan perilaku
seseorang.Pengetahuan merupakan domain yang sangat penting dalam membentuk perilaku seseorang. Sedangkan dari faktor pengalaman dan penelitian terbukti bahwa sikap dan perilaku yang didasari oleh pengetahuan akan lebih langgeng daripada yang tidak didasari oleh pengetahuan.

Selain itu ibu nifas yang memiliki pengetahuan baik tetapi memiliki sikap negatif berjumlah 3 responden (23,1\%). Hal ini disebabkan meskipun ibu nifas mempunyai pengetahuan baik tetapi mereka bersikap negatif dikarenakan pengaruh lingkungan yang tidak mendukung pelaksanaan tentang pijat oksitosin sebagai langkah untuk mengatasi ketidaklancaran ASI.Sehingga ibu nifas memiliki 
sikap yang negatif tentang pijat oksitosin.

Hal ini sejalan dengan teori yang diungkapkan Azwar (2014) yang menyatakan bahwa kebudayaan dimana kita hidup dan dibesarkan mempunyai pengaruh besar terhadap pembentukan sikap, apabila kita hidup dalam budaya yang mempunyai norma longgar bagi pergaulan heteroseksual, sangat mungkin kita akan mempunyai sikap yang mendukung terhadap masalah kebebasan pergaulan heteroseksual. Apabila kita hidup dalam budaya sosial yang sangat mengutamakan kehidupan berkelompok, maka sangat mungkin akan mempunyai sikap negatif terhadap kehidupan individualisme yang mengutamakan kepentingan perorangan.

Selain itu ibu nifas yang memiliki pengetahuan cukup dengan sikap positif berjumlah 5 orang ibu nifas $(45,5 \%)$ dan ibu nifas yang memiliki sikap negatif berjumlah 6 (54,5\%). Dari hasil ini dapat disimpulkan bahwa ibu nifas yang memiliki pengetahuan cukup dengan sikap negatif lebih besar dibandingkan dengan ibu nifas yang memiliki pengetahuan cukup dengan sikap positif. Hal ini dikarenakan dengan pengetahuan yang cukup belum tentu dapat membentuk sikap seseorang untuk menjadi sikap yang positif atau menerima tentang sesuatu hal karena beberapa faktor, seperti orang lain yang dinggap penting. Walaupun seseorang memiliki pengetahuan yang cukup akan tetapi tidak didukung oleh masyarakat atau anggota keluarga yang lain tentunya akan membentuk sikap yang negatif tentang pijat oksitosin.

Serta ibu nifas yang memiliki pengetahuan kurang tentang pijat oksitosin dengan sikap positif berjumlah 2 ibu nifas $(18,2 \%)$ dan pengetahuan kurang ibu nifas tentang pijat oksitosin yang memiliki sikap negatif berjumlah 9 orang ibu nifas $(81,8 \%)$. Responden yang memiliki pengetahuan kurang namun mampu bersikap positif tentang pijat oksitosin dikarenakan pengaruh lingkungan terutam keluarga atau orang lainyang dianggap penting. Biasanya orang akan mengikuti anjuran orang yang dianggap penting walaupun orang tersebut belum memahami tentang pijat oksitosin. Pengaruh dari masyarakat yang memiliki pengetahuan baik tentang pijat oksitosin mempengaruhi responden yang memiliki pengetahuan kurang tersebut mengikuti sikap yang dimiliki oleh masyarakat dan lama kelamaan responden yang memiliki pengetahuan kurang tersebut akan memiliki sikap yang baik seperti masyarakat yang memiliki pengetahuan yang baik dan sikap yang positif.

Analisis uji Chi-Square mendapatkan hasil bahwa nilai pvalue sebesar 0,016 dengan taraf signifikansi $\alpha(0,05)$. Berdasarkan hasil tersebut nilai p-value $0,016<\alpha$ $(0,05)$ sehingga $\mathrm{H}_{0}$ ditolak dan $\mathrm{H}_{\mathrm{a}}$ diterima.Maka dapat disimpulkan bahwa ada hubungan yang signifikan antara pengetahuan dengan sikap ibu nifas tentang pijat oksitosin di Puskesmas Bergas Kabupaten Semarang Tahun 2020. Adanya hubungan antara pengetahuan dengan sikap di sebabkan pengetahuan yang baik akan diwujudkan dalam sikap yang positif. Terbentuknya suatu sikap dimulai pada domain kognitif dalam arti, subjek tahu terlebih dahulu terhadap stimulus yang berupa materi atau objek di luarnya sehingga menimbulkan pengetahuan baru pada subjek tersebut dan selanjutnya 
menimbulkan respons dalam bentuk sikap terhadap objek yang diketahui tersebut.

Hal ini sesuai dengan teori Green dalam Notoatmodjo (2010) bahwa pengetahuan merupakan faktor predisposisi yang menentukan terbentuknya sikap dan perilaku seseorang.Pengetahuan merupakan domain yang sangat penting dalam membentuk perilaku seseorang. Sedangkan dari faktor pengalaman dan penelitian terbukti bahwa sikap dan perilaku yang didasari oleh pengetahuan akan lebih langgeng daripada yang tidak didasari oleh pengetahuan.

Hasil penelitian ini di dukung penelitian oleh Novita A. (2016) menunjukkan bahwa ada hubungan antara pengetahuan ibu nifas dengan sikap melakukan pijat oksitosin di BPM Isna Junaedi Dusun Bandungan Gedangan Kecamatan Tuntang Kabupaten Semarang dengan nilai $(\mathrm{p}=0,009)$. Adanya hubungan antara pengetahuan ibu nifas dengan sikap melakukan pijat oksitosin disebabkan pengetahuan responden yang sebagian besar cukup tentang pijat oksitosin. Hal ini sejalan pula dengan penelitian terdahulu yaitu jurnal internasional yang dilakukan Owupotu Christiana, dkk (2015) yang berjudul Knowledge and Attitute of Men About Vaectomy as a Method of Family Planning Among Marries Men Working in Babcock University, Ogun State Nigeria yang menunjukkan bahwa terdapat hubungan yang signifikan antara tingkat pengetahuan dan sikap melakukan vasektomi.

\section{KESIMPULAN}

Dari hasil penelitian yang dilakukan di Puskesmas bergas tahun 2020, maka dapat disimpulkan bahwa, Pengetahuan tentang pijat oksitosin pada ibu nifas di Puskesmas Bergas Kabupaten Semarang Tahun 2020 sebagian besar memiliki pengetahuan baik yaitu sejumlah 13 orang $(37,2 \%)$. Sikap ibu nifas tentang pijat oksitosin di Puskesmas Bergas Kabupaten Semarang Tahun 2020 sebagian besar memiliki sikap negatif yaitu 18 orang $(51,4 \%)$. Terdapat hubungan pengetahuan dengan sikap ibu nifas tentang pijat oksitosin di Puskesmas Bergas Kabupaten Semarang Tahun 2020 dengan uji Chi Square diperoleh nilai p-value 0,016 . Oleh karena $p$-value $0,016<\alpha(0,05)$.

\section{DAFTAR PUSTAKA}

Amarwati, Vera. (2019). Asuhan Kebidanan Pada Ibu Nifas Dengan Pijat Oksitosin Menggunakan Minyak Aromaterapi Lavender Di Bpm Een Nurhidayati S.Sit Keb , Kalongan, Ungaran Timur, Kabupaten Semarang. Ungaran. Akbid Ngudi Waluyo. Diakses dari http://repository2.unw.ac.id/i d/eprint/504

Andriyani, Novita. (2016). Hubungan Pengetahuan Ibu Nifas Tentang Pijat Oksitosin Dengan Sikap Ibu Melakukan Pijat Oksitosin Si BPM Isna Junaedi. Semarang: Akbid Ngudi Waluyo. Diakses dari https://docplayer.info/448095 54

Arniyanti, Andi dan Dian A. (2019). Pengaruh Pijat Oksitosin Terhadap Produksi ASI Pada Ibu Post Partum di Rumah Sakit Khusus Daerah Ibu dan Anak Siti Fatimah 
Makassar.Makassar. Diakses dari

https://doi.org/10.51171/a.v1

$0 \mathrm{i} 1.129$

Asih, Yusari dan Risneni. (2016). Dokumentasi Kebidanan. Jakarta Timur: CV. Trans Info Media

Astuti, H. P. (2011). Hubungan Karakteristik Ibu Hamil dengan Tingkat Pengetahuantentang Tanda Bahaya pada Kehamilan di Puskesmas Sidoharjo Kabupaten Sragen.Jurnal Stikes Kusuma Husada Surakarta. Diakses dari https:jurnal.ukh.ac.id

Ayu, Firriantin W, Dkk. (2014). Perbedaan Antara Dilakukan Piijatan Oksitosin Dan Tidak Dilakukan Pijatan Oksitosin Terhadap Produksi Asi Pada Ibu Nifas Di Wilayah Kerja Puskesmas Ambarawa. Ungaran: Akbid Ngudi Waluyo. Diakses dari https:jurnal.unimus.ac.id

Christiana, Owopetu, dkk. (2015). Knowledge And Attitude Of Men About Vasectomy As a Methode Of Family Planning Among Married Men Working In Babcock University, Ogun State, Nigeria.Ogun. Diakses dari

http://www.academicjournals. org/IJNM

Dewi, Etika dan Adiratna Sekar.(2018). Faktor-faktor Yang BerhubunganDengan Tingkat Pengetahuan Ibu Dalam Penanganan Demam
Pada Anak Di Puskesmas I Kembaran Kabupaten

Banyumas.Purwokerto.

Diakses dari https:ojs.akbidyllp.ac.id

Dinas Kesehatan Provinsi Jawa Tengah. (2019). Profil Kesehatan Jawa Tengah. Jawa Tengah

Dinas Kesehatan Kabupaten Semarang.(2019). Profil Kesehatan Kabupaten Semarang. Semarang

Fikawati, Sandra; dkk. (2015). Gizi Ibu dan Bayi. Jakarta: PT Rajagrafindo Persada Jakarta: Salemba Medika 